\title{
Adaptive changes in thyroid function of female rats fed a high-fat and low-protein diet during gestation and lactation
}

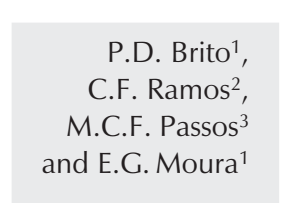

\author{
${ }^{1}$ Departamento de Ciências Fisiológicas, ${ }^{2}$ Departamento de Anatomia, \\ Instituto de Biologia, ${ }^{3}$ Departamento de Nutrição Aplicada, Instituto de Nutrição, \\ Universidade do Estado do Rio de Janeiro, Rio de Janeiro, RJ, Brasil
}

\author{
Correspondence \\ E.G. Moura \\ Departamento de Ciências \\ Fisiológicas \\ Instituto de Biologia, UERJ \\ Av. 28 de setembro, 87, 5ㅇandar \\ 20550-030 Rio de Janeiro, RJ \\ Brasil \\ Fax: +55-21-2587-6121 \\ E-mail: egberto@pesquisador.cnpq.br \\ Research supported by CNPq, \\ FAPERJ, and Pós-Graduação \\ em Biologia (PGBN-UERJ). \\ P.D. Brito was the recipient \\ of a CAPES fellowship.
}

Received March 10, 2005

Accepted February 8, 2006

\section{Abstract}

The percent of lipids in the western diet has been continuously increasing in the last decades and is associated with a decrease in the proportion of protein intake. Recently, we demonstrated that protein malnutrition during lactation is associated with lower body weight and thyroid hypofunction in female rats and their offspring. Our objective in the present study was to determine if a high-fat and lowprotein diet was associated with similar changes. Three-month-old female Wistar rats were randomly assigned to one of the following groups with 8 animals each: high-fat and low-protein (40\% lipid, 5\% protein, and 55\% carbohydrate of the total energy content) from the 3 rd week of gestation to the end of lactation; control group - standard diet (11\% lipid, 23\% protein, and 66\% carbohydrate of the total energy content). Food consumption and body weight were monitored daily. Serum thyrotropin and thyroid hormone concentrations were determined by specific radioimmunoassay at the end of lactation. Animals receiving high-fat and low-protein diet had a significantly lower body weight $(13.9 \%$ at weaning, $\mathrm{P}<0.05)$ and serum albumin $(25 \%, \mathrm{P}<0.05)$ and thyrotropin $(26.2 \%, \mathrm{P}<0.01)$ concentrations, and a higher serum triiodothyronine concentration $(74 \%, \mathrm{P}<0.005)$ and ${ }^{131}$ I-thyroid uptake $(77 \%, \mathrm{P}<0.005)$. These data show that a high-fat and low-protein diet can promote maternal thyroid hyperfunction that differs from the thyroid hypofunction observed in dams fed a lowprotein diet, a phenomenon that can be of adaptive importance for pup nurturing.

\section{Introduction}

In recent years, attention has been focused on the effects of diet on cardiovascular and metabolic diseases. Many experimental and epidemiological studies have implicated
Key words

- High-lipid diet

- Low-protein diet

- Thyroid function

- Lactation
- Gestation 
tein malnutrition to a gradual increase in dietary lipid content, also observed in the poorest populations $(4,5)$. This dramatic increase in lipids in the westernized diet has not been properly studied regarding its physiological consequences during the perinatal period.

Some investigators have shown that the nutritional status of the mother during the gestational and lactational periods is essential to normal growth and development in humans (6-8) and in experimental animals (9-15).

Many experimental studies with high-fat diets have been used to study the effects of their consumption during gestation and lactation on nutrient intake, growth and survival of the pups. For the dams, the data are contradictory. The ingestion of a highfat diet during gestation leads to a higher body weight gain by the mothers $(14,16$, 17). However, when this diet is given throughout gestation and lactation, the dams only maintain the body weight gained during pregnancy $(14,17)$ or even suffer a large body weight loss (16). A high-fat diet seems to cause an increase in plasma triiodothyronine $\left(\mathrm{T}_{3}\right)$ levels in adult animals, suggesting that, through their actions on brown adipose tissue, thyroid hormones have an important thermogenic regulatory role that is essential for the maintenance of body weight (18-20).

Table 1. Macronutrient composition of the control and the high-fat, low-protein diets.

\begin{tabular}{lcc}
\hline Macronutrient composition & Control diet & High-fat, low-protein diet \\
\hline Protein & 23.0 & 6.8 \\
Carbohydrate & 67.6 & 66.1 \\
Fat & 5.0 & 24.2 \\
Saturated fatty acid & $15.5 \%$ & $52 \%$ \\
Polyunsaturated fatty acid & $58 \%$ & $3 \%$ \\
Monounsaturated fatty acid & $23 \%$ & $22 \%$ \\
Cholesterol & $0 \%$ & $0.1 \%$ \\
Total energy (kJ/100 g) & 1711.1 & 2139.5 \\
\hline
\end{tabular}

Data are reported as $\mathrm{g} / 100 \mathrm{~g}$ diet and percent of total fat. Control diet is the standard diet for rats according to AIN-93G recommendations for rodent diets (22).
We have recently shown that proteinrestricted lactating dams present a loss of body weight gain (12), alterations in milk composition (11) and an important adaptive change in thyroid function by increasing the transfer of iodine and $\mathrm{T}_{3}$ through the milk to their pups, probably preventing an eventual neonatal hypothyroidism $(9,10,12)$.

In the present study, we determined if a high-fat and low-protein diet can cause changes in the body weight and thyroid function of lactating rats and if these changes are similar to those observed in animals submitted to protein and energy restriction.

\section{Material and Methods}

Wistar rats were kept in a room with controlled temperature $\left(25 \pm 1^{\circ} \mathrm{C}\right)$ and with an artificial dark-light cycle (lights on from 7:00 am to 7:00 pm). Two 3-month-old virgin female rats were caged with one male rat. The use and handling of experimental animals followed the principles described in the Guide for the Care and Use of Laboratory Animals (21).

After mating, female rats were placed in individual cages and randomly assigned to one of the following groups with 8 animals each: high-fat and low-protein diet (HF/LP), with free access to a high-fat diet from the 3 rd week of gestation to the end of lactation (40\% lipid, 5\% protein, and 55\% carbohydrate of the total energy content); control, with free access to a stock diet (11\% lipid, $23 \%$ protein, and $66 \%$ carbohydrate of the total energy content). The diets were prepared based on a stock commercial diet (Nuvilab, Nuvital Nutrients Ltda., Curitiba, PR, Brazil). The composition of the diets is shown in Table 1 and is based on recommended standards (22). The high-fat and low-protein diet was adapted from previous studies $(14,16,17)$. The amounts of stock and high-fat diet eaten were measured daily.

Within $24 \mathrm{~h}$ of birth, excess pups were removed, so that only 6 male pups remained 
per dam because this procedure maximizes lactation performance (23).

Maternal body weight was monitored daily throughout the end of gestation and lactation. Serum albumin concentrations were measured at weaning (day 21).

On the day of sacrifice (day 21), the animals received a single intraperitoneal (ip) injection containing $2.22 \times 10^{4} \mathrm{~Bq}$ of ${ }^{131} \mathrm{I}$ (IPEN, São Paulo, SP, Brazil). After $2 \mathrm{~h}$, they were killed with a lethal dose of pentobarbital and blood was obtained by cardiac puncture. The thyroid gland was excised and weighed and thyroid ${ }^{131}$ I uptake was evaluated with a gamma counter (Cobra Autogamma, Packard Instrument Co., Downers Grove, IL, USA).

$\mathrm{T}_{3}$ and tetraiodothyronine $\left(\mathrm{T}_{4}\right)$ were measured by commercial RIA adapted for rat serum, as described previously (24). Thyrotropin (TSH) was measured with a rat specific kit provided by the National Institute of Diabetes and Digestive and Kidney Diseases (Bethesda, MD, USA) and results are reported in terms of the reference preparation (RP3). All assays were done with the same lot of reagents and at the same time, and the intra-assay coefficients of variation were: $4.5 \%$ for $\mathrm{T} 3,4.0 \%$ for $\mathrm{T} 4$ and $6.8 \%$ for TSH.

\section{Statistical analysis}

Two-way ANOVA was used to analyze the changes in food ingestion and body weight, and to test the effects of diet and time, followed by the Bonferroni post-test when $\mathrm{P}<0.05$. The Student $t$-test was applied to the data obtained on the 21st (last) day. The data are reported as means \pm SEM and the level of significance was set at $\mathrm{P}<$ 0.05 .

\section{Results}

Mothers on a high-fat, low-protein diet (group HF/LP) presented lower food con- sumption (40\%, $\mathrm{P}<0.001$, Figure $1 \mathrm{~A})$, with a reduction of $82 \%$ in protein intake $(\mathrm{P}<$ 0.001 , Figure $2 \mathrm{~B}$ ) and of $42 \%$ in carbohydrate $(\mathrm{P}<0.001$, Figure $2 \mathrm{D})$ intake soon after the beginning of diet ingestion. Energy intake was lower $(\mathrm{P}<0.05$, Figure $2 \mathrm{~A})$ in this group on days 19 and 20, reaching a $23 \%$ lower level at parturition. However, fat intake was three times higher $(\mathrm{P}<0.001$, Figure 2C) during gestation. At the end of lactation, those differences were $46 \%$ lower for energy $(\mathrm{P}<0.001$, Figure $3 \mathrm{~A}), 65 \%$ for protein $(\mathrm{P}<0.001$, Figure $3 \mathrm{~B})$ and $60 \%$ for carbohydrate intake $(\mathrm{P}<0.001$, Figure 3D) and $44 \%$ higher for fat intake $(\mathrm{P}<0.01$, Figure 3C) compared to control. The rate of carbohydrate/lipid consumed during lactation was lower for the HF/LP group (4.4 x 13.5).

The body weight gains during pregnancy and lactation are shown in Figure 4. At the end of pregnancy, HF/LP mothers showed a lower body weight gain, but at the beginning and in the middle of lactation, the mean body weights of HF/LP mothers did not differ
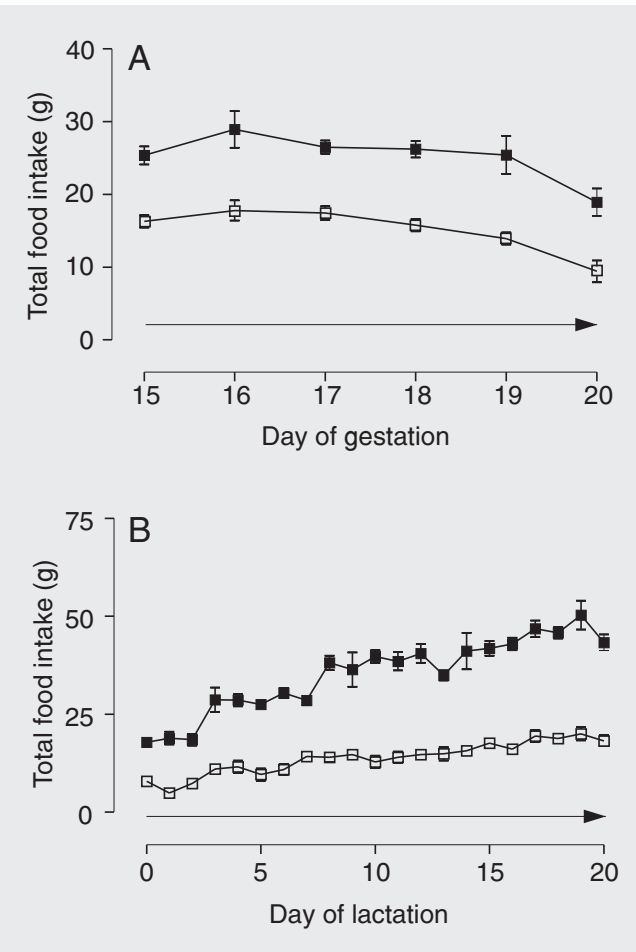

Figure 1. Total food intake by control dams (filled squares) and dams receiving a high-fat and low-protein diet (open squares) from day 15 of gestation to parturition (A) and from birth to weaning (B). The comparison was made for each day and the arrow indicates that the significance occurred during all the period. Data are reported as means \pm SEM for 8 animals per group. $A, \mathrm{~F}=133$ for diet and 8.8 for time $(\mathrm{P}<0.0001$, twoway ANOVA; $P<0.001$, Bonferroni post-test). $B, F=1400$ for diet and 26.2 for time $(P<$ 0.0001 , two-way ANOVA; $P<$ 0.001 , Bonferroni post-test). 
Figure 2. Energy (A), protein (B), lipid (C), and carbohydrate (D) intake by control dams (filled squares) and dams receiving a high-fat and low-protein diet (open squares) during gestation. The comparison was made for each day and the arrow indicates that the significance occurred during all the period. Data are reported as means \pm SEM for 8 animals per group. $A, \mathrm{~F}=$ 32.3 for diet and 8.3 for time $(\mathrm{P}<$ 0.0001, two-way ANOVA; P < 0.05 , Bonferroni post-test). $B, F$ $=718.5$ for $\operatorname{diet}(P<0.0001)$ and 4.9 for time $(P=0.0006$; twoway ANOVA; $\mathrm{P}<0.001$, Bonferroni post-test). $C, F=423.3$ for diet and 10.3 for time $(P<$ 0.0001 , two-way ANOVA; $P<$ 0.001 , Bonferroni post-test). $D$, $F=146$ for diet and 8.8 for time $(\mathrm{P}<0.0001$, two-way ANOVA; $\mathrm{P}$ $<0.001$, Bonferroni post-test).

Figure 3. Energy (A), protein (B), lipid (C), and carbohydrate (D) intake of control dams (filled squares) and dams receiving a high-fat and low-protein diet (open squares), during lactation. The comparison was made for each day and the arrow indicates that the significance occurred during all the period. Data are reported as means \pm SEM for 8 animals per group. $A, \mathrm{~F}=$ 952.5 for diet and 36.7 for time $(\mathrm{P}<0.0001$, two-way ANOVA; $\mathrm{P}$ $<0.001$, Bonferroni post-test). $B$, $F=1574$ for diet and 23.7 for time $(P<0.0001$, two-way ANOVA; $\mathrm{P}<0.001$, Bonferroni post-test). $C, \mathrm{~F}=126.5$ for diet and 10.1 for time $(P<0.0001$, two-way ANOVA; ${ }^{*} \mathrm{P}<0.05$ and $+P<0.01$, Bonferroni post-test). $D, F=988.5$ for diet and 24.1 for time $(P<0.0001$, two-way ANOVA; $\mathrm{P}<0.001$, Bonferroni post-test).
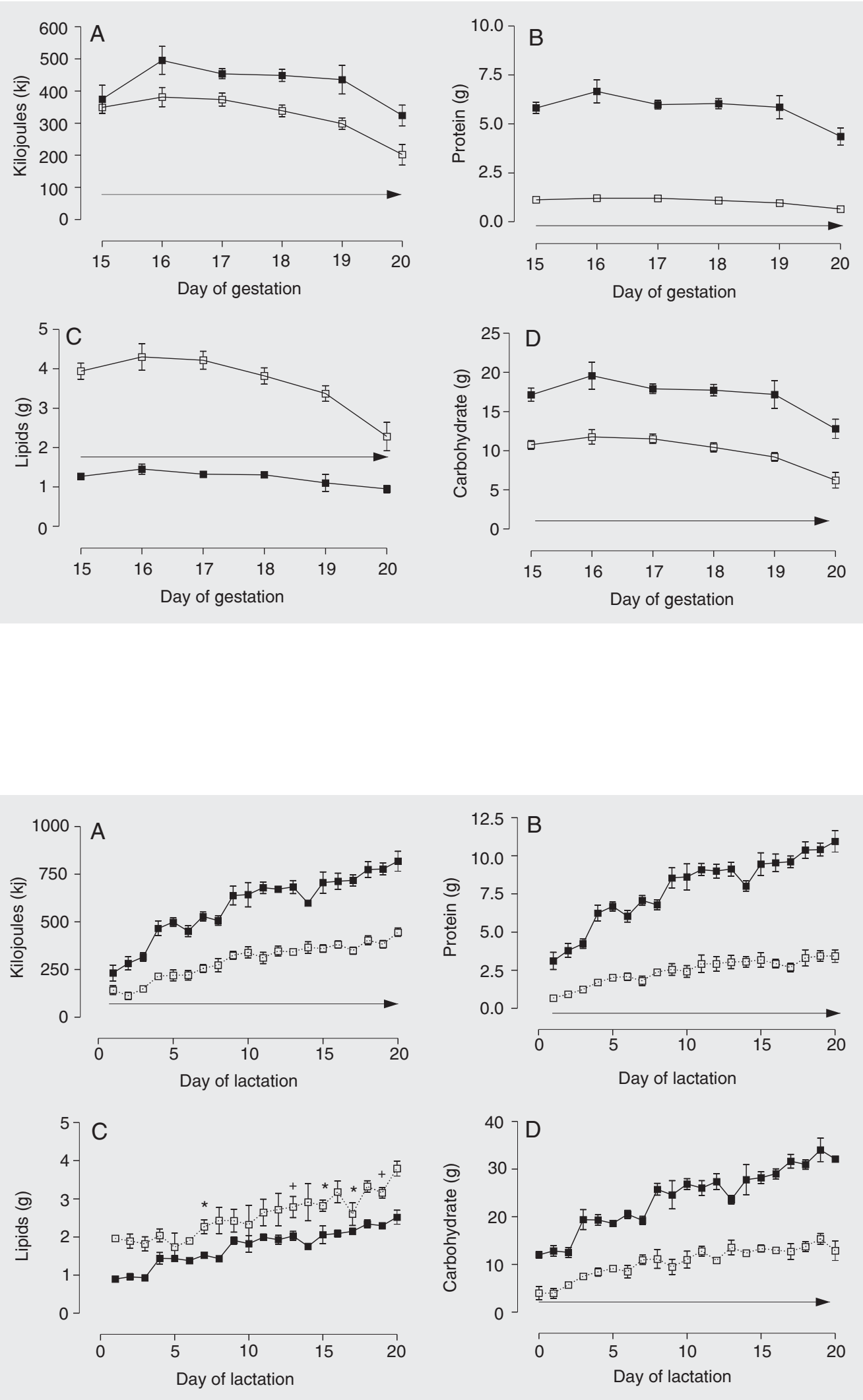
from controls. At the end of lactation, body weight was $14 \%$ lower $(\mathrm{P}<0.05)$ compared to control.

At the end of lactation, HF/LP mothers had lower $(25 \%, \mathrm{P}<0.05)$ serum albumin concentrations, confirming the low protein status of the dams.

Table 2 shows that thyroid radioiodine uptake was higher $(77 \%, \mathrm{P}<0.005)$ in the HF/LP group. Serum TSH concentration was lower $(26 \%, \mathrm{P}<0.01)$, serum $\mathrm{T}_{3}$ was higher $(74 \%, \mathrm{P}<0.005)$ but no changes were found in serum $\mathrm{T}_{4}$ concentration.

\section{Discussion}

The high-fat and low-protein diet used in the present study was based on several models (14,16,25-27). In all of these studies, a low-protein, high-fat and high-calorie diet was used.

The dams that received the high-fat and low-protein diet presented a decrease in total food intake. The same alteration was also described in animals that received a cafeteria diet $(14,16)$ or protein- and energy-restricted diets $(12,28,29)$. Furthermore, since the high-fat diet is instituted abruptly during the third week of gestation, the novelty of the diet could create a food avoidance behavior that could explain the early reduction of food ingestion.

Some investigators have reported that the consumption of diets with high levels of carbohydrates could reduce the total food intake. This could be explained by the higher serotonin production with the ingestion of these diets $(30,31)$. In protein-restricted diets, in which the protein is replaced with corn starch to maintain the energy content of the diet (12), the reduction in food intake could be explained by the higher proportion of carbohydrate in the diet. However, the diet used in the present experiment contained essentially the same amount of carbohydrate as the control diet, suggesting that other nutrients, perhaps protein, lipid, or both, could be responsible for the reduction in food intake observed.

The reduction of energy intake may explain the lower body weight in the HF/LP group that was also found in another study during pregnancy (16). However, we cannot rule out the possibility that the higher lipid content of the diet might lead to a disabsorptive process, thus contributing to the lower body weight.

As also reported by others, a high-fat diet has a low-protein content $(16,32)$, a fact that can explain why HF/LP dams had low serum albumin levels. Naismith et al. (15) have shown that low-protein diets cause somatic

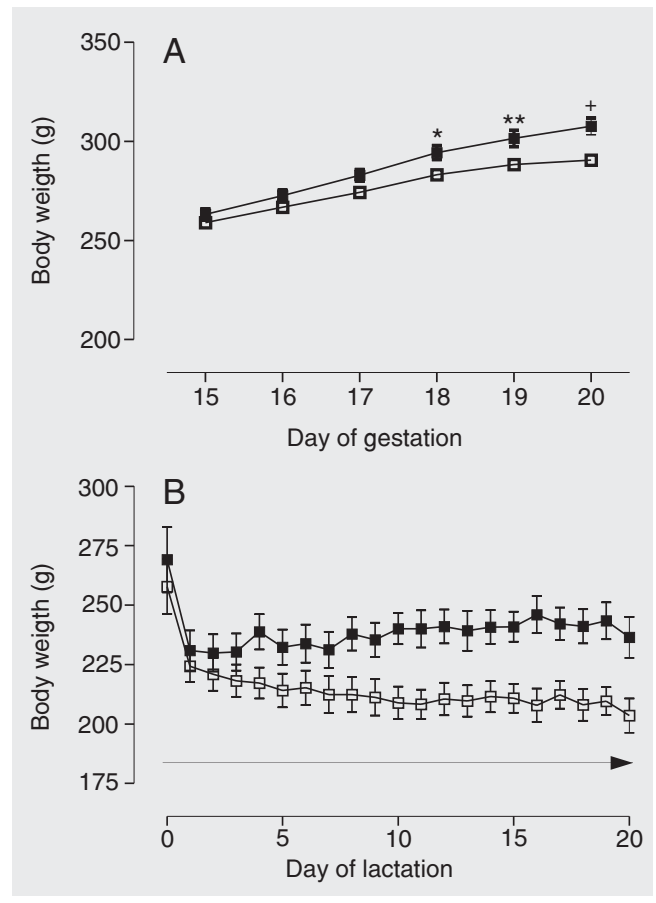

Figure 4. Body weight from day 15 of gestation to parturition (A) and from pup birth to weaning (B) of dams fed a normal (filled squares) and high-fat, low-protein diet (open squares) throughout this period. Data are reported as the means \pm SEM for 8 animals per group. $A, \mathrm{~F}=37.6$ for diet and 55.4 for time $(P<$ 0.0001, two-way ANOVA; ${ }^{*} \mathrm{P}<$ $0.05,{ }^{* *} \mathrm{P}<0.01$ and $+\mathrm{P}<0.001$, Bonferroni post-test). $B, F=$ 111.5 for diet and 2.6 for time $(P$ $<0.0001$, two-way ANOVA; $\mathrm{P}<$ 0.05 , Bonferroni post-test). The arrow indicates that the significance occurred during all the period.
Table 2. Two-hour ${ }^{131}$ I thyroid uptake and serum $\mathrm{T}_{3}, \mathrm{~T}_{4}$ and TSH concentrations on day 21 of dams receiving the control and the high-fat, low-protein diets.

\begin{tabular}{lcc}
\hline & Control diet group & High-fat, low-protein diet group \\
\hline 131/ thyroid uptake & $0.079 \pm 0.0138$ & $0.140 \pm 0.0123^{\star *}$ \\
Serum $\mathrm{T}_{3}(\mathrm{ng} / \mathrm{dL})$ & $28.17 \pm 3.82$ & $49.05 \pm 17.43^{\star *}$ \\
Serum $\mathrm{T}_{4}(\mathrm{ng} / \mathrm{dL})$ & $2.90 \pm 0.13$ & $2.54 \pm 0.15$ \\
Serum TSH $(\mu \mathrm{g} / \mathrm{mL})$ & $1.22 \pm 0.1$ & $0.90 \pm 0.04^{*}$
\end{tabular}

Data are reported as means \pm SEM for 8 animals in each group. ${ }^{*} \mathrm{P}<0.01$ and ${ }^{* *} \mathrm{P}<$ 0.005 compared to control diet (Student $t$-test). 
protein catabolism in the dams in the attempt to maintain adequate milk energy content. It seems that adaptive mechanisms play an important role by guaranteeing a normal milk supply to the pups at the expense of several maternal metabolic and hormonal changes.

We have shown that protein-restricted diets lead to a decrease in ${ }^{131}$ I thyroid uptake and to higher serum TSH and lower $\mathrm{T}_{4}$ concentrations, but surprisingly the animals in that study (12) had higher serum $\mathrm{T}_{3}$ concentrations due in part to a higher thyroid $\mathrm{T}_{4}$ to $\mathrm{T}_{3}$ conversion (33). In contrast, energy-restricted mothers had no change in thyroid radioiodine uptake and lower serum $\mathrm{TSH}, \mathrm{T}_{4}$ and $T_{3}$ concentrations. In the protein-restricted mothers, this could be of adaptive relevance, since these animals secreted more $\mathrm{T}_{3}$ in the milk for their progeny (10). In contrast, in the present study we observed a completely different pattern of thyroid dysfunction, with higher thyroid radioiodine uptake, higher serum $\mathrm{T}_{3}$ concentration and lower serum TSH differing from both the protein- and energy-restricted diet. Thus, in the model used in the present study, the combination of energy and protein restriction with a high-fat diet causes thyroid hormone dysfunction that could provide more $\mathrm{T}_{3}$ through the milk, without compromising thyroid function, as in the protein and energy restriction models, since there was higher thyroid uptake and serum $\mathrm{T}_{4}$ concentration was normal. We do not know why the differences in diet composition preserve or impairs thyroid function.

The higher ${ }^{131}$ I thyroid uptake could be consequent to a lower iodine supply caused by a decrease in its absorption. However, there is no report associating a high-fat diet with impairment of iodine absorption. Another important result that weakens the hypothesis of low iodine absorption was the lower serum TSH concentration, which in such situation was expected to be higher. Another possibility is a real increase in io- dine uptake caused by changes in the sodium/iodide symporter (NIS) or in the iodolipids in the thyroid. Chazenbalk et al. (34) have demonstrated that the iodine thyroid uptake could be regulated by iodolipids formed in the thyroid cell. Thus, it is possible that the high lipid intake could change the synthesis of these putative iodolipids and be responsible for the increase in ${ }^{131} \mathrm{I}$ thyroid uptake observed in the HF/LP group, even with low TSH. Rats fed a cholesterol-rich diet showed higher ${ }^{131}$ I thyroid uptake, but, contrary to our study, they showed also higher serum TSH and lower $\mathrm{T}_{3}$ concentrations (35).

There are few studies about high-fat diets and thyroid regulation, and they also showed elevated plasma $\mathrm{T}_{3}$ levels, normal $\mathrm{T}_{4}$, and no report of TSH levels in adult non-pregnant and non-lactating animals $(19,20)$. We also showed a higher serum $T_{3}$ concentration that could be the result of changes in iodine supply. In fact, iodine deficiency is associated with preferential $\mathrm{T}_{3}$ production by the thyroid (36), but, as stated before, the occurrence of iodine deficiency was unlikely in this situation. Thus, our main hypothesis is that this diet induces thyroid hyperfunction, with stimulation of both iodine uptake and thyroid hormone synthesis. In this case, we would expect an increase in serum $\mathrm{T}_{4}$ concentration, which, however, was not observed.

It is possible that this diet could increase $\mathrm{T}_{4}$ deiodination; however, further studies are necessary to confirm this hypothesis. In fact, hyperthyroid states are associated with an increase in type 1 deiodinase activity (37). A high-fat diet can also increase the rate of $\mathrm{T}_{4}$ uptake by target cells (38). It was demonstrated that fatty acids can regulate differently pituitary $\mathrm{T}_{3}$ and $\mathrm{T}_{4}$ uptake (39). Thus, it is possible that a higher $\mathrm{T}_{4}$ uptake caused by the high-fat diet results in a normal serum $\mathrm{T}_{4}$ concentration, but in higher serum $\mathrm{T}_{3}$ levels and a higher thyroid hormone action.

The higher $\mathrm{T}_{3}$ could suppress serum TSH levels even with normal $\mathrm{T}_{4}$, since $50 \%$ of the 
pituitary thyroid hormone receptor binding come from circulating $\mathrm{T}_{3}$ (40). Another possibility is an increase in pituitary $\mathrm{T}_{4}$ deiodination. The higher-lipid and/or low-protein diet could have a direct effect on TSH secretion or influence pituitary $\mathrm{T}_{4}$ uptake or deiodination.
In the present paper, we showed for the first time that the lipid content of the diet can alter the thyroid function of lactating dams. This could be important for maternal adaptive changes and therefore for the pup's hormonal and nutritional status.

\section{References}

1. Barker DJ. In utero programming of cardiovascular disease. Theriogenology 2000; 53: 555-574.

2. Slattery ML, Randall DE. Trends in coronary heart disease mortality and food consumption in the United States between 1909 and 1980. Am J Clin Nutr 1988; 47: 1060-1067.

3. Willett WC. Diet and health: what should we eat? Science 1994; 264: 532-537.

4. Sichieri R, Siqueira KS, Moura AS. Obesity and abdominal fatness associated with undernutrition early in life in a survey in Rio de Janeiro. Int J Obes Relat Metab Disord 2000; 24: 614-618.

5. Popkin BM, Lu B, Zhai F. Understanding the nutrition transition: measuring rapid dietary changes in transitional countries. Public Health Nutr 2002; 5: 947-953.

6. Godfrey KM, Barker DJ. Fetal nutrition and adult disease. Am J Clin Nutr 2000; 71: 1344S-1352S.

7. Phillips DI, Barker DJ, Osmond C. Infant feeding, fetal growth and adult thyroid function. Acta Endocrinol 1993; 129: 134-138.

8. Read WW, Lutz PG, Tashjian A. Human milk lipids. 3. Short-term effects of dietary carbohydrate and fat. Am J Clin Nutr 1965; 17 : 184-187.

9. Passos MC, Ramos CF, Potente Dutra SC, Moura EG. Transfer of iodine through the milk in protein-restricted lactating rats. $J$ Nutr Biochem 2001; 12: 300-303.

10. Passos MCF, Ramos FC, Mouco T, Moura EG. Increase of $T_{3}$ secreted through the milk in protein restricted lactating rats. Nutr Res 2001; 21: 917-924.

11. Passos MCF, Ramos CF, Moura EG. Short and long term effects of malnutrition in rats during lactation on the body weight of offspring. Nutr Res 2000; 20: 1603-1612.

12. Ramos CF, Teixeira CV, Passos MC, Pazos-Moura CC, Lisboa PC, Curty $\mathrm{FH}$, et al. Low-protein diet changes thyroid function in lactating rats. Proc Soc Exp Biol Med 2000; 224: 256-263.

13. Rolls BA, Gurr MI, van Duijvenvoorde PM, Rolls BJ, Rowe EA. Lactation in lean and obese rats: effect of cafeteria feeding and of dietary obesity on milk composition. Physiol Behav 1986; 38: 185190.

14. Rolls BJ, van Duijvenvoorde PM, Rowe EA. Effects of diet and obesity on body weight regulation during pregnancy and lactation in the rat. Physiol Behav 1984; 32: 161-168.

15. Naismith DJ, Richardson DP, Pritchard AE. The utilization of protein and energy during lactation in the rat, with particular regard to the use of fat accumulated in pregnancy. Br J Nutr 1982; 48: 433-441.

16. Rothwell NJ, Stock MJ. Body weight and brown fat activity in hyperphagic cafeteria-fed female rats and their offspring. Biol Neonate 1986; 49: 284-291.

17. Castella J, Alemany M. Thermogenic effects of a "cafeteria" diet on the rat during its reproductive cycle. Comp Biochem Physiol A 1986;
85: 203-206.

18. Ribeiro MO, Lebrun FL, Christoffolete MA, Branco M, Crescenzi A, Carvalho SD, et al. Evidence of UCP1-independent regulation of norepinephrine-induced thermogenesis in brown fat. Am J Physiol Endocrinol Metab 2000; 279: E314-E322.

19. LeBlanc J, Dussault J, Lupien D, Richard D. Effect of diet and exercise on norepinephrine-induced thermogenesis in male and female rats. J Appl Physiol 1982; 52: 556-561.

20. Tulp OL, Gregory MH, Danforth Jr E. Characteristics of diet-induced brown adipose tissue growth and thermogenesis in rats. Life Sci 1982; 30: 1525-1530.

21. Bayne K. Revised guide for the care and use of laboratory animals available. American Physiological Society. Physiologist 1996; 39: 208-211.

22. Reeves PG, Nielsen FH, Fahey Jr GC. AIN-93 purified diets for laboratory rodents: final report of the American Institute of Nutrition ad hoc writing committee on the reformulation of the AIN-76A rodent diet. J Nutr 1993; 123: 1939-1951.

23. Fischbeck KL, Rasmussen KM. Effect of repeated reproductive cycles on maternal nutritional status, lactational performance and litter growth in ad libitum-fed and chronically food-restricted rats. $J$ Nutr 1987; 117: 1967-1975.

24. Ramos CF, Lima AP, Teixeira CV, Brito PD, Moura EG. Thyroid function in post-weaning rats whose dams were fed a low-protein diet during suckling. Braz J Med Biol Res 1997; 30: 133-137.

25. Berraondo B, Marti A, Duncan JS, Trayhurn P, Martinez JA. Upregulation of muscle UCP2 gene expression by a new beta3-adrenoceptor agonist, trecadrine, in obese (cafeteria) rodents, but downregulation in lean animals. Int J Obes Relat Metab Disord 2000; 24: 156-163.

26. Roca P, Rodriguez AM, Oliver P, Bonet ML, Quevedo S, Pico C, et al. Brown adipose tissue response to cafeteria diet-feeding involves induction of the UCP2 gene and is impaired in female rats as compared to males. Pflugers Arch 1999; 438: 628-634.

27. Zhou X, De Schepper J, De Craemer D, Delhase M, Gys G, Smitz J, et al. Pituitary growth hormone release and gene expression in cafeteria-diet-induced obese rats. J Endocrinol 1998; 159: 165-172.

28. Pine AP, Jessop NS, Oldham JD. Maternal protein reserves and their influence on lactational performance in rats. 3. The effects of dietary protein restriction and stage of lactation on milk composition. Br J Nutr 1994; 72: 815-830.

29. de Mello MA, Oliveira-Filho RM, Cury L, Valle LB. Circulating thyroid hormone levels in young pregnant rats and their fetuses: effect of malnutrition. Ann Nutr Metab 1989; 33: 181-187.

30. Anderson GH, Li ET, Glanville NT. Brain mechanisms and the quantitative and qualitative aspects of food intake. Brain Res Bull 1984; 12: 167-173. 
31. Wurtman RJ. Behavioural effects of nutrients. Lancet 1983; 1: 11451147.

32. Tyzbir RS. Altered brown adipose tissue mitochondrial function in neonates born to rats overfed foods of various protein content. $J$ Nutr 1984; 114: 234-237.

33. Lisboa PC, Passos MC, Dutra SC, Santos RS, Bonomo IT, Cabanelas AP, et al. Increased 5'-iodothyronine deiodinase activity is a maternal adaptive mechanism in response to protein restriction during lactation. J Endocrinol 2003; 177: 261-267.

34. Chazenbalk GD, Pisarev MA, Juvenal GJ, Kleiman de Pisarev DL, Mercuri $\mathrm{H}$, De Tomas M. Biosynthesis and regulation of iodolipids in calf thyroid. Acta Endocrinol 1985; 108: 72-78.

35. Bianco AC, Nunes MT, Martins Jr O, Roesner I, Douglas RA, Pereira $\mathrm{RC}$, et al. Possible mechanism of action of cholesterol enriched diet on the thyroid. Endocrinol Exp 1981; 15: 277-285.

36. Taurog A, Dorris ML. A reexamination of the proposed inactivation of thyroid peroxidase in the rat thyroid by propylthiouracil. Endocrinology 1989; 124: 3038-3042.

37. Bianco AC, Salvatore D, Gereben B, Berry MJ, Larsen PR. Biochemistry, cellular and molecular biology, and physiological roles of the iodothyronine selenodeiodinases. Endocr Rev 2002; 23: 38-89.

38. Benvenga S, Robbins J. Thyroid hormone efflux from monolayer cultures of human fibroblasts and hepatocytes. Effect of lipoproteins and other thyroxinetransport proteins. J Endocrinol 1998; 139: 4311 4318.

39. Everts ME, Lim CF, Moerings EP, Docter R, Visser TJ, de Jong M, et al. Effects of a furan fatty acid and indoxyl sulfate on thyroid hormone uptake in cultured anterior pituitary cells. Am J Physiol 1995; 268: E974-E979.

40. Larsen PR, Silva JE, Kaplan MM. Relationships between circulating and intracellular thyroid hormones: physiological and clinical implications. Endocr Rev 1981; 2: 87-102. 